\title{
A Vida Íntima da Nação
}

\author{
MARTHA CELIA RAMÍREZ-GÁLVEZ
}

\section{ROHDEN, Fabíola.}

A arte de enganar a natureza:

contracepção, aborto e infanticídio no início do século $X X$. Rio de Janeiro: Editora FIOCRUZ, 2003. 248 p.

A arte de enganar a natureza trata dos embates morais, políticos, médicos e jurídicos embasados nas representações, idéias e práticas sobre o controle da natalidade, no Brasil, no início do século XX. Particularmente, propõese a discutir como o controle da natalidade passou a constituir assunto de interesse público, no período analisado, através da apropriação de tais questões por parte do saber médico e de seus desdobramentos no campo jurídico.

Tal empreitada requereu um grande e bem-sucedido esforço da autora, traduzido no cuidado com que os argumentos vão sendo apresentados, documentados e encadeados, atentando para o contexto social mais amplo de constituição do Estado, em uma ordem social capitalista, na qual a saúde, principalmente dos futuros cidadãos, passou a ocupar lugar eminentemente político.

É nesse contexto que pode ser compreendido o domínio médico e jurídico no controle e formação de cidadãos sadios, assim como o embate sobre a quem corresponde explicitar e intervir uma ordem considerada natural - da qual a reprodução se torna expressiva - para operar seu domínio através da regulação social. Nesse contexto, então, localiza-se a incursão da medicina no campo jurídico - este, outro regulador do comportamento sexual e reprodutivo: "O juiz interroga para surpreender na mentira; o médico interroga para assegurar-se da verdade. O juiz interroga como homem; o médico como um Deus. As leis escritas são da alçada do juiz; a natureza inteira é do médico" (AZEVEDO JUNIOR, 1852, p. 6, apud ROHDEN, 2003, p. 48).

O livro nos informa não somente acerca da institucionalização de um saber que procura "traduzir para a sociedade os desígnios naturais", a partir de um discurso considerado científico, racional e objetivo. Apesar de serem identificados discursos e práticas dominantes que se impõem de tempos em 
tempos, a autora também traz à cena práticas "desviantes" e mecanismos de regulação interna da atuação médica, que se tornam públicos a partir de seu caráter criminal.

Não obstante, na pesquisa de Rohden os diálogos vão além do julgamento e/ou resolução de casos individuais. As conexões remetem a um aspecto demográfico que se ocupa da qualidade da população, colocando em relação a medicina com o poder público; a medicina com o Estado. A referência a idéias e práticas higienistas, eugenísticas, torna-se um tema ineludível para compreender o contexto da época e como a sexualidade e a reprodução se tornaram assunto político, negócio de Estado, ligado à "intimidade da nação". A proposta do médico Tito Livio de Castro - narrada pela autora, acerca de uma "medicina demográfica" que forneceria dados para a elaboração de projetos a serem implementados pelo governo " constitui uma proposta expressiva do lugar determinante da medicina na constituição de discursos normativos, no estabelecimento de políticas sobre o corpo, a sexualidade e a reprodução.

Nesse processo, a Ginecologia se configura no saber que, por excelência, descrevia, compreendia e, portanto, prescrevia funções que adequassem os papéis de mulheres e homens à construção da Nação. No cerne desses debates e discursos encontravam-se, principalmente, as mulheres, responsabilizadas pela "produção" de novos e bons indivíduos, que garantissem a perpetuação e qualidade da espécie. Elas passaram a ser alvo de vigilância, perdendo a qualidade de sujeito individual, sendo que seus "enganos à natureza" ou atos considerados desviantes dos desígnios naturais são qualificados como crime ou insanidade mental.

Um aspecto do livro que merece destaque diz respeito às questões metodológicas. A autora constrói interessante campo etnográfico a partir de múltiplas e diversas fontes. O saber médico da época é mapeado através de periódicos, livros, boletins, anais de congressos e, principalmente, das teses defendidas na antiga Faculdade de Medicina do Rio de Janeiro. O campo jurídico é cercado por todos os processos e inquéritos de algumas cidades do Rio de Janeiro, sobre aborto, infanticídio, aparecimento e ocultação de feto, entre 1890 a 1940, armazenados no Arquivo Nacional. A análise desses processos requereu, por sua vez, consulta a manuais de medicina legal e revistas de jurisprudência.

Mas o mérito não se esgota no uso e articulação de fontes de diversa natureza, contexto e autoria, mas no desafio de capturar e analisar esse campo 
etnográfico, reconstruído no seu conjunto. A partir dessa estratégia metodológica, de uma antropologia histórica, Rohden traça não só o contexto, mas coloca a descoberto as relações que ajudam a estruturar uma totalidade que fala da regulação da vida dos indivíduos do período estudado e de seu papel na constituição de uma nação. De modo mais específico, recria o que acontecia na academia de medicina e como isso se traduzia no campo jurídico, reconstruindo as diversas versões dos agentes implicados, seus significados e embates identificados nesse campo social.

Ao inferir as práticas, valores de uma época passada, a análise da lógica interna desses documentos traz à tona lutas de classe, estigmatização de grupos sociais e o modo como os mecanismos de controle cercaram as estratégias de reação às normas, qualificadas como criminais ou patológicas. As mulheres foram o alvo principal dos mecanismos de tutela médica e jurídica, já que se concebia o controle delas como necessário para uma evolução mais rápida e fácil da população.

O sistema que articulava honra, família e nação prescrevia relações diferenciadas por gênero, classe e raça, sendo que as mulheres pobres estavam ausentes na formulação de um discurso hegemônico, de um modelo de família e valores dominantes entre os médicos e juristas - que faziam as normas -, mas presentes no ato da punição. O debate natureza / cultura, constante na discussão antropológica sobre diferenças sexuais, gênero e reprodução, é recorrente ao longo do livro.

Esse trabalho não só procura recriar o início do século XX, quanto aos discursos e práticas em relação ao controle da sexualidade e da reprodução, mas também traz a relação dessa bagagem na organização social, presente de maneira característica, segundo a autora, na chamada "Era Vargas", na qual foram redobradas a valorização da maternidade e a implementação de políticas de proteção e de assistência à maternidade e à infância, visando a garantir o capital humano da nação.

Cabe também destacar que, embora uma empreitada que vise a dar conta da configuração de um campo possa se ressentir no aprofundamento do mesmo, a autora é cuidadosa ao identificar e explicitar as limitações do trabalho, orientando o leitor interessado para uma vasta e seleta bibliografia complementar.

Ainda que o conteúdo do livro nos remeta ao início do século XX, torna-se difícil para o leitor familiarizado com esse campo não estabelecer, 
também, conexões com o contexto contemporâneo da reprodução assistida. Quase um século depois do período pesquisado por Rohden, é tentador pensar mais nas permanências do que nas mudanças. As primeiras, possivelmente herdadas de uma tradição médica de normalização e normatização dos comportamentos sexuais e reprodutivos.

Se, no início do século XX, o problema da esterilidade era atribuído às mulheres - ou, no melhor dos casos, considerava-se que $60 \%$ das causas eram da mulher e $40 \%$ do homem -, atualmente observamos que estas são distribuídas "equiitativamente" entre os sexos - tentativa que, no entanto, fica somente no nível das definições. Embora se pretenda equilibrar as causas da infertilidade, não acontece o mesmo com as intervenções médico-químicas implementadas para a consecução do sonhado filho, que continuam tendo como alvo principal o corpo das mulheres.

Por outro lado, atualmente, a valorização da maternidade aparece travestida no discurso da autodeterminação e das escolhas reprodutivas, porém, em última instância, remete ao cumprimento de um imperativo de reprodução para o qual, se for necessário, os limites etários do ciclo reprodutivo são expandidos. Se antes, como mostra Fabíola Rohden, para os médicos e higienistas da época o instinto materno era corrompido pelos avanços da civilização, atualmente a medicina reprodutiva é chamada a responder ao adiamento da maternidade, permitindo à "mulher liberada" o reencontro e cumprimento dos desígnios de uma natureza recriada segundo os moldes culturais (RABINOW, 1999) $)^{2}$, realizando o imperativo de que as mulheres, tarde ou cedo, devem ser mães. Em última instância, hoje, como naquela época, assistimos à recuperação do instinto materno, abalado pelo "[...] excesso de civilização, educação e trabalho".

\section{NOTAS}

${ }^{1}$ Doutora em Ciências Sociais pelo Instituto de Filosofia e Ciências Humanas da UNICAMP. Bolsista do Programa de Formação de Quadros Profissionais do CEBRAP e pesquisadoracolaboradora do Núcleo de Estudos de Gênero (PAGU / UNICAMP). E-mail: marthace@obelix.unicamp.br

${ }^{2}$ RABINOW, P. Artificialidade e Iluminismo: da sociobiologia à biossociabilidade. In: RABINOW, P. Antropologia da razão: ensaios de Paul Rabinow. Organização e tradução de João Guilherme Biehl. Rio de Janeiro: Relume Dumará, 1999. 